\title{
PEMIDANAAN PELAKU ANCAMAN KEKERASAN DENGAN CARA MENAKUT-NAKUTI MELALUI MEDIA SOSIAL (STUDI PUTUSAN NOMOR.1210/PID.SUS/2018/PN.MDN)
}

\author{
Resi Ratna Sari Br Sembiring, Haposan Siallagan, Roida Nababan \\ Fakultas Hukum, Universitas HKBP Nommensen \\ haposansiallagan@uhn.ac.id
}

\begin{abstract}
Abstrak
Media elektronik yang banyak dipergunakan masyarakat dalam kegiatan sehari-hari yakni telepon gengam (handphone). Seiring dengan penggunaan media eletktonik yang demikian pesat, ternyata diikuti dengan tumbuhnya tindak pidana. Bentuk kejahatan dunia maya pada masa sekarang ini sangatlah banyak seperti penghinaan baru dengan menggunakan media elektronik seperti telepon gemgam berupa penipuan, pencemaran dan bahkan melakukan pengancam dengan cara menakut-nakuti melalui media sosial. Metode yang digunakan adalah penelitian kepustakaan (library research) yaitu pengumpulan data yang dilakukan dengan cara menghimpun data yang berasal dari kepustakaan, berupa peraturan perundang-undangan, buku-buku yang ada kaitannya dengan masalah yang diteliti Berdasarkan hasil penelitian yang dilakukan pada Putusan Nomor 1210/Pid.sus/2018/PN.Mdn maka dapat disimpulkan dasar pertimbangan Hakim terdakwa telah melanggar Pasal 45B jo Pasal 29 UU RI No. 19 Tahun 2016 Tentang Informasi dan Transaksi Elektronik dengan Pidana penjara 4 (empat) bulan dan denda Rp. 2.000.000,00 (Dua Juta Rupiah) disebabkan terdakwa Liwi Alias Virgo Hwang Alias Virgo yang telah melakukan tindak pidana ancaman kekerasan dengan cara menakut-nakuti melalui media sosial dalam studi putusan Nomor 1210/Pid.Sus/2018/PN.Mdn telah terbukti dan meyakinkan.
\end{abstract}

\section{Kata Kunci: Pemidanaan, Ancaman, Kekerasan, Media Sosial}

\begin{abstract}
The electronic media that is widely used by the community in their daily activities is mobile phones. Along with the use of electronic media which is so rapid, it turns out that criminal acts are growing. There are many forms of cybercrime today, such as new insults using electronic media such as phone calls in the form of fraud, defamation and even threatening by means of scare through social media. The method used is library research (library research), which is data collection carried out by collecting data from libraries, in the form of laws and regulations, books that are related to the problem under study. Based on the results of research conducted in Decision Number 1210 / Pid.sus / 2018 / PN.Mdn, it can be concluded that the basis for the judgment of the accused had violated Article 45B in conjunction with Article 29 of the Republic of Indonesia Law No. 19 of 2016 concerning Information and Electronic Transactions with imprisonment for 4 (four) months and a fine of Rp. 2,000,000.00 (Two Million Rupiah) because the defendant Liwi Alias Virgo Hwang Alias Virgo had committed a criminal act of threatening violence by means of frightening through social media in the study of verdict Number 1210 / Pid.Sus / 2018 / PN.Mdn which and convincing.
\end{abstract}

Keywords : Criminalization, Threats, Violence, Social Media 
PATIK : JURNAL HUKUM Vol : 09 No. 3, Desember 2020, Hal 227 - 239

\section{Pendahuluan}

Ilmu pengetahuan dalam bidang teknologi telah berkembang dengan sangat pesat, salah satu produk dari teknologi tersebut ialah teknologi informasi ataupun teknologi telekomunikasi.Telekomunikasi adalah setiap pemancaran, pengiriman, dan/atau penerimaan dari setiap informasi dalam bentuk tanda-tanda, isyarat, tulisan, gambar, suara dan bunyi melalui sistem kawat, optik, radio atau sistem elektronik lainnya.

Salah satu media elektronik yang banyak digunakan masyarakat dalam kegiatan sehari-harinya yakni telepon genggam (handphone). Keberadaan telepon genggam adalah memudahkan individu untuk berbicara dengan orang lain tanpa harus bertemu dengan orang tersebut ditambah dibatasi oleh ruang, jarak dan waktu. Telepon genggam adalah alat komunikasi yang hampir semua orang memiliki, baik untuk melakukan panggilan atau mengirim pesan. Maka banyak pihak yang menggunakan handphone atau teknologi untuk melakukan kejahatan. Kejahatan dalam bidang teknologi informasi (cybercrime) adalah kejahatan yang menggunakan komputer sebagai sasaran kejahatan. Kejahatan ini adalah kejahatan dalam pengertian yuridis yaitu tindak pidana yang diatur dalam peraturan perundang-undangan. Bentuk-bentuk kejahatan dunia maya pada masa sekarang ini sangatlah banyak seperti penghinaan, penipuan, pencemaran nama baik, pemerasan dan pengancaman kekerasan melalui media elektronik.

Setiap orang berhak mendapatkan rasa aman dan nyaman tanpa adanya gangguan apapun. Dengan demikian seseorang akan dapat merasakan ketentraman bebas dari segala bentuk ancaman serta ketakutan yang selalu menghantui. Ancaman kekerasan bukan hanya bisa terjadi melalui pertemuan langsung namun seiring berjalannya waktu ada banyak aplikasi yang dapat digunakan untuk menyampaikan pesan ancaman kekerasan. Maka setiap orang harus mendapat rasa aman dan tentram tanpa adanya gangguan dan tidak mengurangi hak asasi manusia.

Perkembangan teknologi informasi dan komunikasi dapat mempermudah manusia dan menjalankan aktivitasnya namun disisi lain dapat menimbulkan berbagai masalah seperti munculkan bentuk kejahatan atau tindak pidana yang bervariasi. Media elektronik berupa handphone merupakan salah satu teknologi yang dipakai manusia untuk melakukan kejahatan atau tindak pidana seperti ancaman kekerasan melalui layanan pesan singkat (WhatApp).

Kekerasan adalah perbuatan dengan menggunakan kekuatan fisik yang besar atau cukup besar, yang mengakibatkan orang yang dipaksa tidak berdaya secara fisik. Sementara pada ancaman kekerasan melalui media elektronik wujud nyata kekerasan belum dilakukan. Namun telah menimbulkan rasa cemas dan takut akan benar-benar akan diwujudkan. Karena itu ketidakberdayaan akibat dari ancaman kekerasan bersifat psikis. Akibat ketidakberdayaan itulah yang menyebabkan orang yang dipaksa menyerahkan barang membuat utang atau mengapuskan piutang yang dimaksud.

Masalah pelanggaran atau kejahatan mengancam dengan cara menakut-nakuti merupakan suatu perbuatan yang melanggar hukum karena meresahkan dan melanggar hak asasi orang lain. Selain itu juga mengancam orang melalui media sosial dengan cara menghina dan mencemarkan nama baik seseorang akan mudah masyarakat lain menerima informasi privasi tersebut dan dengan cepat informasi tersebar luas yang berakibatkan korban malu, terhina dan tertekan atas ancaman dari pelaku pada dirinya. Ancaman kekerasan yang dilakukan pelaku di media sosial saat ini cenderung untuk memenuhi hasrat atau ingin memperoleh sesuatu dari korban, sehingga hal ini nantinya akan membuat korban mengalami ketakutan yang cukup besar yang nantinya akan merugikan dirinya.

${ }^{1}$ Adami Chazawi, Ardi Ferdian, Tindak Pidana Informasi \& Transaksi Elektronik, Media Nusa Creative, Malang, 2015, hlm 121-122. 
Pelaku yang melakukan ancaman kekerasan di media sosial saat ini berkembang sangat cepat setiap tahunnya, seperti pada data yang dikelurkan oleh southeast asia freedom of expression net work ( SAFENet) Indonesia mencatat ada 381 kasus UU ITE sepanjang 2011-2019 yang menjerat perorangan ataupun institusi. Jika merujuk pada situs registrasi MA ada 508 perkara di pengadilan yang menggunakan UU ITE sepanjang 20112018. Kasus paling besar terjadi pada 2018 yaitu 292 perkara, angka ini meningkat dibanding tahun 2017 sebanyak 140 kasus. Kasus terbanyak adalah pidana yang berhubungan dengan penghinaan dan pencemaran nama baik yakni pasal 27 ayat (3) UU ITE dan di posisi kedua adalah kasus ujaran kebencian pada pasal 28 ayat 2 UU ITE. ${ }^{2}$

Tindak pidana ancaman kekerasan yang dilakukan melalui media sosial diatur dalam KUHP pasal 369 yang berbunyi "Barangsiapa dengan maksud untuk menguntungkan diri sendiri atau orang lain secara melawan hukum, dengan ancaman pencemaran baik dengan lisan maupun tulisan atau dengan ancaman akan membuka rahasia, memaksa seorang supaya memberikan barang sesuatu yang seluruhnya atau sebagian kepunyaan orang itu atau orang lain, atau supaya memberi utang atau menghapuskan piutang, diancam dengan pidana penjara paling lama empat tahun. Ketentuan pasal tersebut, jika dikaitkan dengan pola baru dalam kejahatan ancaman dengan WhatsApp, maka ini dirasakan cukup sulit menjerat pelaku kejahatan ancaman dengan WhatsApp menggunakan Pasal dalam KUHP. Untuk mengatur tata cara penggunaan teknologi informasi dan komunikasi di Indonesia, pemerintah mengeluarkan Undang-Undang Nomor 11 Tahun 2008 tentang Informasi dan Transaksi Elektronik (ITE). Tindak Pidana Ancaman di dalam UU ITE diatur dalam Undang-Undang Nomor 19 Tahun 2016 tentang perubahan atas Undang-Undang nomor 11 Tahun 2008 tentang Informasi dan Transaksi Elekronik yaitu Pasal 45B jo Pasal 29 yaitu "Setiap orang dengan sengaja dan tanpa hak mengirimkan informasi Elektronik dan/atau Dokumen Elektronik yang berisi ancaman kekerasan atau menakut-nakuti yang ditujukan secara pribadi."

Di dalam kasus putusan yang diteliti oleh penulis, dimana terdakwa telah melakukan tindak pidana acaman kekerasan dan pencemaran nama baik yang melanggar Pasal 45B jo Pasal 29 yaitu "Setiap orang dengan sengaja dan tanpa hak mengirimkan informasi Elektronik dan/atau Dokumen Elektronik yang berisi ancaman kekerasan atau menakut-nakuti yang ditujukan secara pribadi”. Dimana dalam kasus ini terdakwa mengancam korban yakni akan mencemarkan nama baik si korban dan terdakwa juga menakut-nakuti korban dengan video kekerasan dikirimkan melalui aplikasi whatsapp yang sangat meresahkan terdakwa, hal itu dilakukan terdakwa karena orangtua korban tidak melunasi hutang dan janjinya terhadap terdakwa. Akibat perbuatan terdakwa, korban merasa terancam dan korban mengalami gangguan psikis serta rasa ketakutan yang mendalam sehingga korban dan orangtua korban melaporkan tindakan terdakwa tersebut kepada pihak berwajib karena merasa sudah tidak aman dengan tindakan yang dilakukan oleh terdakwa kepada korban.

\section{Tinjauan Pustaka}

Pertimbangan atau yang sering disebut juga considerans merupakan dasar putusan Hakim atau argumentasi Hakim dalam memutuskan suatu perkara. Jika argumen hukum itu tidak benar dan tidak sepantasnya (proper), maka orang kemudian dapat menilai bahwa

${ }^{2}$ Safenet.or.id/wp-content/uploads/2019/06/laporan-tahunan-SAFEnet-2018.pdf, pada tanggal 4 Agustus 2020 pukul 14.14 WIB. 
putusan itu tidak benar dan tidak adil ${ }^{3}$. Kemudian menurut Sudikno Mertokusumo, secara sederhana putusan hakim mencakup irah-irah dan kepala putusan, pertimbangan, dan amar. Dari cakupan itu, yang dipandang sebagai dasar putusan adalah pertimbangan. Alasanalasan yang kuat dalam pertimbangan sebagai dasar putusan membuat putusan yang hakim menjadi objektif dan beribawa ${ }^{4}$.

Paradigma berpikir atau dasar pertimbangan hakim sangat penting guna menentukan isi dari suatu putusan. Putusan hakim merupakan bagian hasil dari pola pikir hakim. Hakim sebagai penegak hukum dan keadilan wajib menggali, mengikuti dan memahami nilai-nilai hukum yang hidup dalam masyarakat dan dalam mempertimbangkan berat ringannya pidana, hakim wajib memperhatikan pula sifat-sifat yang baik dan jahat dari yang tertuduh. ${ }^{5}$

Ancaman adalah janji atau niat seseorang yang akan melakukan sesuatu yang tidak dikehendaki oleh dan sangat mengkhawatirkan bagi orang yang menerima ancaman apabila sesuatu yang diinginkan oleh orang yang menyampaikan ancaman tersebut tidak dipenuhi oleh pihak yang menerima ancaman. ${ }^{6}$ Kekerasan adalah suatu perbuatan dengan menggunakan tenaga atau kekuatan jasmani secara tidak sah dan membuat orang tidak berdaya. ${ }^{7}$ Kata kekerasan dalam frasa ancaman kekerasan mengandung arti perbuatan (aktif atau fisik) orang dengan menggunakan kekuatan fisik yang besar/kuat, atau menggunakan kekuatan yang lebih dari biasanya (hetaanwenden van kracht vanenige betekenis).

Sementara pada ancaman kekerasan, kekuatan fisik yang besar tadi belum diwujudkan, namun akan diwujudkan/terwujud yang menyebabkan orang yang dituju merasa khawatir, cemas dan ketakutan. Misalnya ancaman akan dibunuh atau akan di pukul. Menakut-nakuti dengan ancaman kekerasan tersebut menimbulkan perasaanperasaan sangat tidak menentramkan jiwa penderita batiniah. ${ }^{8}$ Menakut-nakuti dengan ancaman kekerasan dinilai membahayakan keselamatan yang sangat beresiko. Kekerasan dapat terjadi dalam dua bentuk yaitu kekerasan fisik yang mengakibatkan kematian dan kekerasan psikis yang tidak berakibatkan pada fisik korban melainkan timbulnya trauma berkepanjangan pada diri korban. Ancaman kekerasan dapat dilakukan berupa ucapan, tulisan, gambar baik dengan maupun tanpa sarana dalam. Ancaman ini dilakukan di media sosial dengan sengaja untuk mempersenjatai dan menyalahgunakan media sosial untuk mengirimkan pesan singkat yang isinya mengancam dengan kata-kata yang tidak patut kepada orang lain. Pada pasal 89 KUHP juga di atur mengenai tindak pidana kekerasan yang berbunyi : Membuat orang jadi pingsan atau tidak berdaya disamakan dengan menggunakan kekerasan (KUHP 55, 146 dst, 170, 173, 175, 211 dt., 285, 289, 293, 300, $330,332,335,365,368,438$ dst, 444, 459, dst). Tindak pidana ancaman di dalam UndangUndang ITE daiatur dalam pasal 29 UUITE.

\footnotetext{
${ }^{3}$ Hukum.studentjournal.ub.ac.id/index.php/hukum/article/download/542/532, Dasar Pertimbangan
} Hakim Dalam Penjatuhan Putusan Pidana Bersyarat Sebagai ALternatif Pidana Penjara, Malang, hal 6, diakses pada Rabu 5 Agustus 2020. Pukul 17.10.

${ }^{4}$ Ibid, hal 7

${ }^{5}$ Jonaedi Efendi, Rekonstruksi Dasar Pertimbangan Hakim Berbasis Nilai-Nilai Hukum Dan Rasa

Keadilan Yang Hidup Dalam Masyarakat, Prenada Media Group, Depok, 2018, hal 264.

${ }^{6}$ Budi Suhariyanto, Tindak Pidana Teknologi Informasi (Cybercrime), Raja Grafindo Persada, 2012, hal 123.

${ }^{7}$ Maidin Gultom, Perlindungan Hukum Terhadap Anak dan Perempuan, Refika Aditama, Bandung, 2014, hal 1.

${ }^{8}$ Adami Chazawi dan Ardi Ferdian, Op.Ci, hal 136. 
Istilah media sosial tersusun dari dua kata, yakni "media" dan "sosial". Media adalah lembaga yang bertugas menyampaikan dan memperluas informasi. Sebagai sebuah lembaga, media dituntut untuk menyampaikan hak pada penggunaan informasi, sebut saja masyarakat. ${ }^{9}$ Sosial menurut Kamus Besar Bahasa Indonesia (KBBI) adalah berkenaan dengan masyarakat. ${ }^{10}$ Jadi media sosial adalah informasi yang bebas dan luas yang berkenaan di masyarakat. Pemilik akun media sosial bisa berbuat apa saja karena tidak disensor. Misalnya, mereka bisa ngumpat apa saja, ngomong apa saja, menyebarkan tautan apapun dan menulis beragam kalimat dan mengirimkan foto serta apa saja yang ia suka.

Seorang yang berpendidikan tinggi yang biasa jadi teladan pun bisa terpancing untuk memprovokasi pengguna media sosial, bahkan jauh dari etika komunikasi. Mereka tidak mengindahkan apakah yan dikirim itu menyinggung orang lain atau tidak, membuat orang lain marah atau tidak. Ia tidak pernah berpikir soal itu. Intinya mereka berbuat sesuai keinginannya. Begitu beragam informasi yang disajikan lewat media sosial membuktikan betapa masyarakat mempunyai kebebasan berpendapat. ${ }^{11}$

Pengertian cybercrime, komputer-related dapat disamakan dengan istilah tindak pidana di bidang teknologi dan informasi. ${ }^{12}$ Cybercrime merupakan keseluruhan bentuk kejahatan yang ditujukan terhadap komputer, jaringan komputer, para penggunanya, dan bentuk-bentuk kejahatan konvensional yang menggunakan atau dengan bantuan peralatan komputer. Kejahatan tersebut dibedakan menjadi 2 kategori yakni, cybercrime dalam pengertian sempit dan dalam pengertian luas. Cybercrime dalam pengertian sempit adalah kejahatan terhadap sistem komputer, sedangkan dalam arti luas mencakup terhadap sistem atau jaringan komputer dan kejahatan yang menggunakan sarana komputer. ${ }^{13}$

Dengan demikian dapat dipahami bahwa pengertian cybercrime adalah setiap aktivitas seseorang, sekelompok orang, badan hukum yang menggunakan komputer sebagai sarana kejahatan. Kejahatan tersebut adalah bentuk-bentuk kejahatan yang bertentangan dengan peraturan perundang-undangan, baik melawan hukum secara material maupun melawan hukum secara formal. ${ }^{14}$ Sehingga dapat dikatakan bahwa teknologi informasi dan komunikasi bagaikan pedang bermata dua, dimana selain memberikan kontribusi positif bagi peningkatan kesejahteraan, kemajuan, dan peradaban manusia juga menjadi sarana potensial dan sarana efektif untuk melakukan perbuatan melawan hukum.

Perbuatan melawan hukum di dunia maya merupakan fenomena yang sangat mengkhawatirkan mengingat tindakan carding, hacking, penipuan, terorisme dan penyebaran informasi deduktif telah menjadi bagian dari aktivitas pelaku kejahatan di dunia maya. Oleh karena itu untuk menjamin kepastian hukum pemerintah berkewajiban melakukan regulasi terhadap berbagai aktivitas terkait dengan pemanfaatan teknologi informasi dan komunikasi tersebut. ${ }^{15}$

Membahas aturan hukum cybercrime merupakan suatu hal yang memiliki tantangan tersendiri. Hal ini dikarenakan peraturan perundang-undangan yang mengatur tentang kejahatan siber di Indonesia masih "seumur jagung". Aturan perundang-undangan

${ }^{9}$ Nurudin, Media Sosial (Agama Baru Masyarakat Milenial), Intrans Publisishing, Malang, 2019, hal 93.

${ }^{10}$ Kamus Besar Bahasa Indonesia (KBBI) Edisi Kelima, 2016, hal 1586.

${ }^{11}$ Nurudin, Op. Cit, hal 4.

${ }^{12}$ Widodo, Hukum Pidana di Bidang Teknologi dan Informasi (Cybercrime Law: Telaah Teoritik da $n$ Bedah Kasus), CV Aswaja Pressindo, Yogyakarta, 2011, hal 9.

${ }^{13}$ Ibid, hal 12.

${ }^{14}$ Ibid, hal 13.

${ }^{15}$ Siswanto Sunarso, Hukum Informasi dan Transaksi Elektronik, Rineka Cipta, Jakarta, 2019, hal 40. 
telah dituangkan dalam Undang-Undang Nomor 11 Tahun 2008 tentang Informasi dan Transaksi Elektronik. ${ }^{16}$

\section{Metode}

Jenis penelitian yang digunakan dalam penelitian ini adalah Yuridis Nornatif. Penelitian hukum normatif adalah penelitian yang dilakukan dengan cara menelusuri atau menelaah dan menganalisis bahan pustaka atau bahan dokumen siap pakai sebagai kajian utama. Penelitian ini disebut juga penelitian kepustakaan (liberary research). Sedangkan pendekatan Metode pendekatan masalah yang digunakan dalam penelitian ini adalah Metode pendekatan kasus (case approach) yaitu dengan cara menganalisis Putusan Nomor 1210/PID.SUS/2018/PN.MDN dan Metode pendekatan Perundang-undangan (statute approach) yang dilakukan dengan menelaah ketentuan perundang-undangan yang berlaku dalam kasus tersebut yaitu Pasal 45B jo Pasal 29 Undang-Undang Republik Indonesia Nomor 19 Tahun 2016 tentang perubahan atas Undang-Undang No.11 Tahun 2008 tentang Informasi dan Transaksi Elektronik.

Berdasarkan sifat penelitian, maka sumber bahan hukum yang digunakan adalah bahan hukum sekunder. Bahan hukum sekunder merupakan bahan hukum yang sudah tersedia dan diolah berdasarkan bahan-bahan hukum. Bahan hukum sekunder, terdiri dari 3 (tiga) jenis bahan hukum yaitu :

a. Bahan Hukum Primer (primary law material)

Yaitu bahan hukum yang mempunyai kekuatan hukum mengikat secara hukum (perundang-undangan) atau mempunyai kekuatan mengikat bagi pihak-pihak yang berkepentingan. Penelitian bahan hukum primer yang digunakan adalah putusan Pengadilan Negeri Medan Nomor 1210/PID.SUS/2018/PN.MDN, Pasal 45 B jo Pasal 29 Undang-Undang RI Nomor 19 Tahun 2016 tentang perubahan atas Undang-Undang RI Nomor 1 Tahun 2008 tentang Informasi dan Transaksi Elektronik dan UndangUndang RI Nomor 8 Tahun 1981 tentang Hukum Acara Pidana.

b. Bahan Hukum Sekunder (secondary law material)

Yaitu bahan hukum yang memberi penjelasan terhadap bahan hukum primer berupa buku-buku teks yang ditulis para ahli hukum, yurisprudensi dan jurnal hukum yang berkaitan dengan topik penelitian.

c. Bahan Hukum Tersier (tertiary law material). ${ }^{17}$

Yaitu bahan hukum yang memberikan penjelasan terhadap bahan hukum primer dan bahan hukum sekunder berupa kamus hukum, pendapat para sarjana, internet dan menyusun secara sistematis.

\section{Pembahasan Dan Hasil}

Pada hari tanggal yang sudah tidak dapat ditentukan lagi pada bulan Mei 2017, terdakwa datang ke rumah saksi Jin Ngi Alias Jimmy yang terletak di Blok S Komplek Graha Medan dengan maksud untuk menemui saksi Jin Ngi Alias Jimmy namun tidak bertemu dan karena tidak bertemu selanjutnya terdakwa meminta nomer handphone saksi korban Thomas Arwitra anak saksi Jin Ngi Alias Jimmy yakni saksi Thomas Arwitra agar dapat berkomunikasi untuk mengetaui keberadaan saksi Jin Ngi Alias Jimmy dan saksi

\footnotetext{
${ }^{16}$ Maskun, Kejahatan Siber (Cyber Crime), Kencana Prenada Media Group, Jakarta, 2013, hal 58.

${ }^{17}$ Ibid, 182.
} 
Thomas Arwitra memberikan nomor 082260686922 yang merupakan nomor ponsel sekaligus nomor akun WhatssAppnya, kemudian pada tanggal 1 Juni 2017 terdakwa dengan meggunakan akun WhatsAppya 082160801010 mengirimkan pesan ke akun WhatsApp nomor milik sa ksi Thomas Arwitra meminta agar saksi Thomas Arwitra mempertemukan terdakwa dengan saksi Jin Ngi Alias Jimmy yang merupakan orangtua saksi Thomas Arwitra, sejak tanggal 2 Juni 2017 terdakwa mulai mengirim pesan yang dikirimkan melalui akun WhatsApp milik terdakwa dengan nomor 082160801010 ke akun WhatsApp milik saksi Thomas Arwitra dengan nomor 082260686922 yang inti pesan tersebut menyebutkan akan menyebarkan berita kepada teman-teman sekolah saksi Thomas Arwitra yang menyatakan bahwa Orang tua saksi Thomas Arwitra adalah Penipu dan Keluarganya hidup mewah, bayar uang sekolah, makan, beli mobil dari hasil Penipuan, kemudian pada tanggal 03 Juni 2017 terdakwa kembali mengirimkan pesan melalui akun WhatsApp yang isinya akan menyuruh orang lain untuk menyelesaikan masalah utang dan penipuan yang dilakukan orang tua saksi Thomas Arwitra tersebut, selanjutnya pada tanggal 05 Juni 2017 terdakwa kembali mengirimkan pesan melalui akun WhatsApp yang isinya akan memberitahukan kepada teman-teman, adik dan orang-orang komplek Cemara Asri bahwa orang tua saksi Thomas Arwitra penipu, kemudian ada tanggal 09 Juni 2017 terdakwa kembali mengirim kiriman Foto dan video tentang perampokan di SPBU Daan Mogot Jakarta yang korbannya ditembak hingga meninggal dunia yang merupakan gambaran yang dapat dilakukan seseorang untuk mencelakai orang lain yang intinya mengancam atau menakut-nakuti saksi Thomas Arwitra dan kelurganya karena orangtuanya telah melakukan penipuan, akibat pesan kiriman dari terdakwa tersebut membuat saksi korban Thomas Arwitra selalu khawatir dan ketakutan bila hendak keluar dari rumah dan berdasarkan keterangan Ahli Psikiater Dra. Irna Minauli, Msi, Psikolog menerangkan bahwa saksi Thomas Arwitra menunjukkan beberapa gelaja Post-Traumatic Stress Disorder yang ditandai dengan perubahan perilaku menjadi sensitive secara emosional, adanya Regresi (kemunduran pada perilaku masa kanak-kanak) terlihat dengan adanya kecemasan yang besar, kurang mandiri dan menjadi sangat bergantung pada orang lain.

Berdasarkan surat dakwaan Jaksa Penuntut Umum No. 1210/Pis.Sus/2018/Pn.Mdn Jaksa mendakwa terdakwa Liwi Alias Virgo Hwang Alias Virgo dengan dakwaan tunggal sebagai berikut:

Perbuatan terdakwa sebagaimana diatur dan diancam pidana dalam Pasal 45 b jo Pasal 29 UU RI No. 19 Tahun 2016 Perubahan Atas UU RI No. 11 Tahun 2008 tentang Informasi Transaksi Elektronik.

Tuntutan Jaksa Penuntut Umum (JPU) kepada Terdakwa Liwi Alias Virgo Hwang Alias Virgo yang diajukan pada Majelis Hakim pada pokoknya sebagai berikut:

1. Menyatakan terdakwa Liwi Alias Virgo Hwang Alias Virgo terbukti bersalah melakukan tindak pidana "Dengan sengaja dan tanpa hak mengirimkan Informasi Elektronik dan/atau Dokumen Elektronik yang berisi ancaman kekerasan atau menakut-nakuti yang ditujukan secara pribadi" melanggar Pasal 29 Jo Pasal 45B UU RI No. 19 Tahun 2016 tentang perubahan atas Undang-Undang RI No. 11 Tahun 2008 tentang Informasi dan transaksi Elektronik.

2. Menjatuhkan pidana penjara terhadap terdakwa Liwi Alias Virgo IIWI Alias Virgo dengan pidana penjara selama 6 (enam) bulan dan denda sebesar Rp. 5.000.000,- (lima juta rupiah) subsideir pidana penjara selama 3 (tiga) bulan.

3. Menyatakan barang terbukti berupa : 
- 1 (satu) unit smart phone OPPO type CPH1613 dengan Imei 1: 86488003182252, Imei 2: 86488003182245 warna hitam

- 3 (tiga) lembar hasil cetakan (print) capture pesan kiriman akun WhatsApp Nomor 082160801010. Seluruhnya dirampas untuk dimusnahkan.

4. Membayar biaya perkara sebesar Rp.5.000,(lima ribu rupiah)

Majelis Hakim Pengadilan Negeri Medan telah memutuskan perkara pada putusan Nomor: 1210/Pid.Sus/2018/PN.MDN dalam sidang terbuka untuk umum dengan amar putusan sebagai berikut:

1. Menyatakan Terdakwa Liwi alias Virgo Hwang alias Virgo tersebut diatas, terbukti secara sah dan meyakinkan bersalah melakukan tindak pidana "Tanpa hak dengan sengaja mengirimkan dokumen elektronik yang bersifat ancaman kekerasan dan menakut-nakuti yang ditujukan secara pribadi “, sebagaimana dakwaan tunggal Penuntut Umum.

2. Menjatuhkan pidana kepadaTerdakwa tersebut oleh karena itu dengan pidana penjara selama 4 (empat) bulan dan denda sejumlah Rp. 2.000.000,00 (dua juta rupiah) dengan ketentuan jika denda tersebut tidak dibayar maka diganti dengan pidana kurungan selama 2 ( dua ) bulan;

3. Menetapkan barang bukti berupa :

- 1 (satu) unit smart phone OPPO type CPH 1613 dengan IMEI 864880031382252 dan IMEI 864880031382245 warna hitam dan 3 ( tiga ) lembar hasil cetakan ( print) capture pesan kiriman akun WhatsApp nomor 082160801010 dirampas untuk dimusnahkan.

4. Membebankan biaya perkara kepada Terdakwa sejumlah Rp.5.000,00 ( lima ribu rupiah).

Pertimbangan atau yang sering disebut juga considerans merupakan dasar putusan Hakim atau argumentasi Hakim dalam memutuskan suatu perkara. Jika argumen hukum itu tidak benar dan tidak sepantasnya (proper), maka orang kemudian dapat menilai bahwa putusan itu tidak benar dan tidak adil. Hakim harus mengikuti dan memahami nilai-nilai hukum dalam penjatuhan pidana terhadap terdakwa. Penjatuhan pidana bisa diartikan sebagai tahap penetapan sanksi dan juga tahap pemberian sanksi dalam hukum pidana. Kata "pidana" pada umumnya diartikan sebagai hukum, sedangkan "penjatuhan pidana" diartikan sebagai penghukuman. Seseorang yang dijatuhi pidana adalah seseorang yang melakukan suatu tindak pidana. Tindak pidana ancaman kekerasan dimaknai sebagai setiap perbuatan secara melawan hukum berupa ucapan, tulisan, gambar, simbol, atau gerakan tubuh baik dengan atau tanpa menggunakan sarana yang menimbulkan rasa takut atau mengekang kebebasan hakiki seseorang. Menakut-nakuti dengan ancaman kekerasan melalui media sosial dinilai membahayakan keselamatan yang sangat beresiko. Kekerasan dapat terjadi dalam dua bentuk yaitu kekerasan fisik yang mengakibatkan kematian dan kekerasan psikis yang tidak berakibatkan pada fisik korban melainkan timbulnya trauma berkepanjangan pada diri korban serta dapat membuat korban malu dan tertekan.

Hakim dalam mempertimbangkan berdasarkan keterangan saksi, keterangan ahli, keterangan Terdakwa dan alat bukti yang dihadirkan dimuka persidangan. Dalam mempertimbangkannya Majelis Hakim memilih Dakwaan tunggal yaitu melanggar Pasal 27 ayat (3) Jo Pasal 45 ayat (1) UU RI No. 11 Tahun 2008 Tentang Informasi dan Transaksi Elektronik Menurut Penulis karena telah terpenuhinya syarat seseorang untuk melakukan pertanggungjawaban serta alat dan barang bukti yang dapat meyakinkan Majelis Hakim, karena tidak ditemukannya unsur dari alasan pembenar maupun alasan pemaaf terhadap tindakan yang dilakukan oleh terdakwa. 
Hakim dalam menjatuhkan pidana haruslah mempertimbangkan unsur-unsur tindak pidana . Berikut merupakan unsur-unsur tindak pidana:

1. Subjek dari pelaku tindakan

Dalam penelitian ini bahwa terdakwa Liwi merupakan orang atau perseorangan yang dapat disebut sebagai subjek hukum, dalam hal ini bahwa terdakwa telah memenuhi salah satu unsur yaitu subjek dari suatu tindak pidana ancaman kekerasan.

2. Kesalahan dari tindakan

Bahwa perbuatan terdakwa yaitu melakukan ancaman kekerasan dengan cara menakut-nakuti yang merupakan kesalahan dalam hukum pidana dimana terdakwa telah melakukan perbuatan yang tidak sesuai dengan undang-undang yang mengatur.

3. Bersifat melawan hukum dari tindakan tersebut

Bahwa perbuatan terdakwa yakni melakukan ancaman kekerasan dengan cara menakut-nakuti adalah perbuatan melawan hukum. Ataupun merupakan perbuatan tindak pidana yang secara sah dan jelas telah melanggar ketentuan undang-undang yang berlaku.

4. Suatu tindakan yang dilarang atau diharuskan oleh undangundang/perundangan dan terhadap pelanggarnya diancam pidana.

Perbuatan terdakwa dalam hal ini yaitu dalam ancaman kekerasan adalah suatu perbuatan yang sangat ditentang dalam undang-undang karena dapat meresahkan masyarakat atau pun perorangan yang mengakibatkan orang tersebut merasa kwatir, panik dan was-was yang dapat merusak mental korban tersebut. Dalam hal ini pula dapat disimpulkan bahwa terdakwa tidak menjalankan undang-undang yang berlaku sebagaimana mestinya.

5. Waktu, tempat dan kejadian suatu tindak pidana.

Bahwa terdakwa melakukan ancaman kekerasan dengan cara menakutnakuti melalui media sosial pada tanggal 03 Juni 2017, 05 Juni 2017 dan 09 Juni 2017.

Berdasarkan paparan penulis diatas bahwa jelas terdakwa telah memenuhi unsurunsur tindak pidana. Dalam menjatuhkan hukuman kepada pelaku tindak pidana ancaman kekerasan dengan cara menakut-nakuti melalui media sosial dalam hal ini terdakwa Liwi alias Virgo Hwang telah terpenuhinya unsur-unsur tindak pidana ancaman kekerasan yakni:

a. Kesalahan: dengan maksud untuk menguntungkun diri sendiri atau orang lain.

b. Melawan hukum: secara melawan hukum.

c. Perbuatan: memaksa orang.

Suatu tindak pidana dapat dijatuhi putusan harus melalui proses pembuktian di persidangan. Pembuktian pada dasarnya adalah ketentuan-ketentuan yang berisi penggarisan dan pedoman tentang cara-cara yang dibenarkan undang-undang untuk membuktikan kesalahan yang didakwakan kepada terdakwa. Pembuktian juga merupakan ketentuan yang mengatur alat-alat bukti yang dibenarkan oleh undang-undang dan boleh dipergunakan Hakim membuktikan kesalahan yang didakwakan.

Terkait dengan pertimbangan Hakim yang tertuang dalam suatu putusan, KUHAP telah mengatur tata cara yang harus di taati oleh Hakim sebelum mengeluarkan putusannya. Majelis Hakim dalam menjatuhkan putusan harus berdasarkan beberapa ketentuan-ketentuan yang terdapat dalam KUHAP, diantaranya adalah ketentuan yang termuat dalam Pasal 183 KUHAP yang berbunyi : "Hakim tidak boleh menjatuhkan pidana 
kepada seseorang kecuali apabila dengan sekurang-kurangnya dua alat bukti yang sah dan ia memperoleh keyakinan bahwa suatu tindak pidana benar-benar terjadi dan bahwa terdakwalah yang bersalah melakukannya."

Selain ketentuan diatas, ketentuan dalam Pasal 193 ayat (1) KUHAP juga menjadi hal yang sama pentingnya untuk diperhatikan. Pasal tersebut berbunyi: "Jika pengadilan berpendapat bahwa terdakwa bersalah melakukan tindak pidana yang didakwakan kepadanya, maka pengadilan menjatuhkan pidana."

Tujuan pemidanaan terhadap terdakwa sebagai berikut:

a. Teori Absolut

Menurut teori absolut, tujuan pemidanaan terletak pada hukum pidana itu sendiri. "Barang siapa yang melakukan suatu perbuatan pidana, harus dijatuhkan hukuman pidana". Teori ini disebut juga teori pembalasan.

b. Teori Relatif

Tujuan dari pemidanan adalah untuk mencegah terjadinya kejahatan, menakut-nakuti, sehingga orang lain tidak melakukan kejahatan, memperbaiki orang yang melakukan tindak pidana, dan memberikan perlindungan kepada masyarakat terhadap kejahatan.

c. Teori Gabungan

Teori ini merupakan kombinasi antara teori absolut dan teori relatif, tujuan penjatuhan pidana karena orang tersebut melakukan kejahatan dan agar ia tidak melakukan kejahatan lagi.

Adapun hakim mempertimbangkan hal-hal yang ditentukan menurut pasal 184 ayat

(1) dan (2) KUHAP atau hal-hal yang bersifat yuridis tentang alat bukti yang sah yaitu :

1. Alat bukti yang sah ialah :

a. Keterangan saksi

- Bahwa benar saksi pernah diperiksa oleh penyidik dan keterangan saksi di berita acara penyidik tersebut benar;

- Bahwa sekira tanggal 2 Juni 2017 sampai 9 Juni 2017 saksi mendapat ancaman, menakut-nakuti, penghinaan atau pencemaran nama baik melalui sosial media Whats App dengan nomor 082160801010;

- Bahwa belakangan saksi mengetahui pemilik akun Whats App nomor 082160801010 tersebut adalah Liwi alias Virgo Hwang alias Virgo ( Terdakwa ) hal tersebut saksi ketahui karena pada bulan Mei 2017, Terdakwa bersama temannya datang ke tempat tinggal saksi untuk menemui orang tua saksi, namun tidak bertemu, lalu Terdakwa minta nomor handphone saksidan berselang beberapa hari kemudian akun whats app saksi menerima pesan dari akun whats app dengan nomor 082160801010 dan setelah saksi cek photo profil dari akun whats app pengirim pesan baru saksi mengetahui bahwa pemilik akun whats app nomor 082160801010 tersebut adalah Terdakwa;

- Bahwa selain itu juga ada dikirimkan gambar photo dan video berupa kejadian pembunuhan di Daan Mogot Jakarta;

b. Keterangan ahli

- Bahwa saksi ahli pernah diperiksa penyidik sehubungan dengan perkara ini dan keterangan saksi ahli di berita acara penyidik tersebut benar; 
c. Barang bukti

Bahwa menurut saksi ahli Andi Zulkarnain SH.,ACE.,MH terdakwa dihadapkan kepersidangan ini sehubungan dengan adanya tindak pidana ancaman kekerasan dengan cara menakut-nakuti melalui media sosial yang dilakukan oleh terdakwa Liwi Alias Virgo Hwang Alias Virgo;

- Bahwa yang saksi jelaskan adalah sehubungan dengan pemeriksaan dan penelitian barang bukti yang diduga digunakan dalam tindak pidana mengirimkan informasi elektronik atau dokumen elektronik yang berisi ancaman kekerasan atau menakut-nakuti yang ditujukan secara pribadi sebagimana dimaksud dalam Pasal 29 jo 45 ayat (3) UURI nomor 19 Tahun 2016 tentang Perubahan atas UURI nomor 11 tahun 2008 tentang ITE;

- 1 (satu) unit handphone OPPO type CPH1613 warna hitam Imei 1864880031382252 , Imei 2864880031382245 warna hitam;

- $\quad 3$ (tiga) lembar hasil cetakan (print) capture pesan kiriman akun WhatsApp nomor 082160801010 ;

d. Keterangan terdakwa

- Bahwa benar Terdakwa pernah diperiksa oleh penyidik dan keterangan di berita acara penyidik tersebut benar;

- Bahwa Terdakwa kenal dengan Thomas Arwitra maupun orang tuanya;

- Bahwa benar pesan WhatsApp yang ada di berkas perkara adalah pesan WhatsApp dari handphone Terdakwa kepada Thomas Arwitra, hal tersebut Terdakwa lakukan karena emosi, karena Thomas Arwitra tidak memberikan nomor handphone orang tuanya kepada Terdakwa, selain itu Terdakwa juga mendapat teror dan mengatakan lonte;

- Bahwa pada awalnya Terdakwa hanya chat biasa saja dengan Thomas Arwitra, kemudian Terdakwa menagih janji Thomas Arwitra untuk mempertemukan Terdakwa dengan orang tuanya, tetapi Thomas Arwitra ingkar janji;

- $\quad$ Bahwa maksud Terdakwa bertemu dengan orang tua Thomas Arwitra untuk menagih utangnya;

- $\quad$ Bahwa Terdakwa tidak membuat postingan ke sekolah Thomas Arwitra maupun ke media sosial lainnya berupa ancaman;

- Bahwa foto dan video yang Terdakwa kirimkan kepada Thomas Arwitra tersebut hanya sebatas foreward saja, foto dan video tersebut Terdakwa peroleh dari group Whats App;

- Bahwa maksud Terdakwa mengirimkan pesan WhatsApp kepada Thomas Arwitra agar Thomas Arwitra mempertemukan Terdakwa dengan orang tuanya;

- Bahwa uang yang dipinjam Jin $\mathrm{Ng}$ alias Jimmy sebesar Rp.400.000.000,00 (empat ratus juta rupiah) tersebut adalah uang simpanan Terdakwa dan uang tersebut dipinjam melalui Anthony tanpa bunga; 
- $\quad$ Bahwa istri Jin Ngi alias Jimmy pernah memberikan cek atas pembayaran uang Rp.400.000.000,00 (empat ratus juta rupiah) tersebut tetapi setelah jatuhtempo ternyata dananya kosong;

- Bahwa Terdakwa menulis kata "hati-hati" di foto kejadian di SPBU Daan Mogot Jakarta tersebut bukan hanya kepada Thomas Arwitra saja tetapi juga kepada yang lainnya, maksud Terdakwa supaya hati-hati saja;

- $\quad$ Bahwa Terdakwa emosi karena Thomas Arwitra mengirimkan pesan WhatsApp dengan kata-kata "rentenir, pelacur";

- Bahwa Terdakwa merasa menyesal dan berjanji tidak mengulangi perbuatan seperti itu.

2. Hal yang secara umum sudah diketahui tidak perlu dibuktikan

Sedangkan hal-hal yang bersifat non-yuridis yaitu:

Hal yang memberatkan:

- Bahwa perbuatan Terdakwa menimbulkan rasa takut dan trauma bagi saksi Thomas Arwitra alias Thomas;

- Bahwa perbuatan Terdakwa menimbulkan rasa malu bagi keluarga Thomas Arwitra alias Thomas;

Hal yang meringankan:

- Bahwa Terdakwa bersikap sopan selama pemeriksaan perkara;

- Bahwa Terdakwa mengakui dan menyesali perbuatannya;

- Bahwa Terdakwa belum pernah dihukum;

Oleh karena itu, sesuai dengan ketentuan yang terdapat dalam Pasal 183 KUHAP yang intinya menyatakan bahwa jika terdapat cukup bukti Majelis Hakim tidak boleh menjatuhkan pidana kepada seseorang jika tidak di dukung dengan 2 (dua) alat bukti yang sah serta keyakinan di mana bahwa persidangan telah terdapat lebih dari 2 (dua) alat bukti yang sah berupa keterangan saksi, alat bukti petunjuk berupa 1 (satu) unit smart phone yang berisi akun Whatsapp, 3 (tiga) lembar hasil cetakan (print) capture pesan kiriman terdakwa, keterangan terdakwa, dan keterangan saksi yang termuat dalam pasal 183 KUHAP telah terpenuhi.

Selain itu, sesuai dengan ketentuan pasal 193 ayat (1) KUHAP yang pada pokoknya pengadilan harus menjatuhkan pidana kepada terdakwa yang bersalah dimana terdakwa Liwi Alias Virgo Hwang Alias Virgo, terbukti secara sah dan meyakinkan bersalah melakukan tindak pidana "Tanpa Hak dengan sengaja mengirimkan dokumen elektronik yang bersifat ancaman kekerasan dan menakut-nakuti yang ditujukan secara pribadi" sebagaimana dalam dakwaan tunggal tersebut, dan Menjatuhkan pidana terhadap terdakwa Liwi Alias Virgo Hwang Alias Virgo, dengan pidana penjara selama 4 (empat) bulan dan denda sejumlah Rp. 2.000.000,00 (dua juta rupiah) dengan ketentuan jika denda tersebut tidak dibayar maka diganti dengan pidana kurungan selama 2 ( dua ) bulan; Berdasarkan pemaparan diatas, bahwa pertimbangan hakim dalam menjatuhkan pidana dalam kasus tindak pidana ancaman kekerasan melalui media sosial diatas telah sesuai dengan ketentuan yang terdapat dalam Pasal 183 dan Pasal 193 ayat (1) KUHAP.

\section{Kesimpulan}

Putusan Hakim dalam menjatuhkan pidana terhadap terdakwa dengan pidana penjara selama 4 (empat) bulan dan denda sejumlah Rp. 2.000.000,00 (dua juta rupiah) dengan ketentuan jika denda tersebut tidak dibayar maka diganti dengan pidana kurungan selama 2 (dua) bulan. Akan tetapi hukuman terhadap terdakwa terlalu ringan karena dalam 
rumusan Pasal 45B jo Pasal 29 UU RI No.19 Tahun 2016 Tentang Informasi Transaksi Elektronik maksimal pidana penjara paling lama 4 (empat) tahun dan/atau denda paling banyak Rp.750.000.000,- (tujuh ratus lima puluh juta rupiah) dan putusan Hakim hanya menjatuhkan pidana kepada terdakwa dengan pidana penjara selama 4 (empat) bulan dan denda sejumlah Rp.2.000.000,- (dua juta rupiah), hal ini lah yang membuat penulis merasa tidak setuju dengan putusan hakim karena menganggap putusan hakim terlalu ringan dari rumusan dalam Pasal 45B jo Pasal 29 UU RI No.19 Tahun 2016 Tentang Informasi Transaksi Elektronik.

Upaya pemberantasan tindak pidana ancaman kekerasan harus dilakukan secara sistematik dan didukung sepenuhnya oleh seluruh lapisan masyarakat dan aparat penegak hukum.

\section{DAFTAR PUSTAKA}

\section{Buku}

Adami Chazawi, Ardi Ferdian, Tindak Pidana Informasi \& Transaksi Elektronik, Malang: Media Creative, 2015.

Adami Chazawi, Hukum Pidana Positif Penghinaan, Malang: Media Creative, 2016.

Adami Chazawi, Pelajaran Hukum Pidana Bagian I, Raja Grafindo, 2020.

Bambang Poemomo, Asas-Asas Hukum Pidana, Jakarta: Ghalia Indonesia, 2014.

Budi Suhariyanto, Tindak Pidana Teknologi Informasi (Cybercrime), Raja Grafindo Persada, 2012.

Gomgom T.P. Siregar, Suatu Analisis Mengenai Tindak Pidana Pencemaran Nama Baik Melalui Media Elektronik, Bandung: Refika Aditama, 2020.

Hasibuan, P., Girsang, S. B. R., Harefa, E. J., Simamora, J., \& Manullang, H. (2020). AKIBAT HUKUM PENCABUTAN BERITA ACARA PEMERIKSAAN SAKSI DI DEPAN PERSIDANGAN DALAM TINDAK PIDANA NARKOTIKA (Studi Putusan Nomor 201/Pid.Sus/2018/PN Simalungun) . Nommensen Journal of Legal Opinion, 1(01), 129-138. https://doi.org/10.51622/njlo.v1i01.341

July Esther dan Anastasya Reni Widiastuti, Hukum Pidana, Medan: Bina Media Perintis, 2013.

Mahrus Ali, Asas-Asas Hukum Pidana Korporasi, Jakarta: Raja Grafindo, 2013.

Maidin Gultom, Perlindungan Hukum Terhadap Anak dan Perempuan, Bandung Refika Aditama, 2014.

Maskun, Kejahatan Siber ( Cyber Crime), Jakarta: Kencana Prenada Media Group, 2013.

Moeljatno, Asas-Asas Hukum Pidana, Jakarta: Rineka Cipta, 2002.

Nurudin, Media Sosial (Agama Baru Masyarakat Milenial), Malang: Intrans Publisishing, 2019.

P.A.F Lamintang, Dasar-Dasar Hukum Pidana Indonesia, Bandung: Citra Aditya Bakti, 2011.

Peter Mahmud Marzuki, Penelitian Hukum, Bandung: Kencana Prenada Media Group, 2010.

Rodliyah dan Salim, Hukum Pidana Khusus (Unsur dan Sanksi Pidananya), Depok: Raja Grafindo Persada, 2017.

Siswanto Sunarso, Hukum Informasi dan Transaksi Elektronik, Jakarta: Rineka Cipta, 2019.

Teguh Prasetyo, Hukum Pidana, Jakarta: Raja wali Pers, 2010. 